\title{
Students' Self-Attitudes and Self-Actualization in the Context of Self-Determination: Analysis of the Empirical Research
}

\section{Самоставлення та самоактуалізація студентської молоді у контексті самодетермінації: аналіз емпіричного дослідження}

\author{
Iryna Yavorska-Vietrova \\ Ph.D. in Psychology, \\ Senior Researcher \\ of the Chamata Laboratory \\ of Psychology of Personality
}

\author{
Ірина Яворська-Ветрова \\ кандидат психологічних наук, \\ старший науковий співробітник \\ лабораторії психології \\ особистості імені П. Р. Чамати
}
E-mail: irinavetrova009@gmail.com orcid.org/0000-0002-6509-930X
Researcher ID: G-4702-2018

Інститут психологї ілені

Г.С. Костюка

НАПН України, Україна

вул. Паньківська, 2,

м. Київ, 01033

Original manuscript received April 15, 2019

Revised manuscript accepted May 11, 2019

\section{ABSTRACT}

The article is devoted to the analysis of the experimental study of correlations between parameters of students' self-attitudes and self-actualization. Self-attitude is defined as a complex multi-level emotional-value system that takes place at certain developmental stages on the basis of active assimilation, integration and hierarchization of information about "Self» and help an 
individual predict his/her social effectiveness and attitude of other towards him/her, regulate interpersonal relationships, set and achieve goals. Selfactualization is understood as a central aspect of personality development and it is a manifestation of the innate tendency for the individuals' natural potential growth. The performed analysis of the survey data on students' selfattitude peculiarities substantiates that their attitudes toward themselves has a pronounced positive emotional modus. There are significant correlations between parameters of self-attitude and self-actualization. Thus, a high positive self-evaluation is related to an individual's ability to appreciate own dignity, to respect him/herself, directly and spontaneously express own feelings, demonstrate emotions, be relatively independent in actions and to the desire to be guided in life by own purposes, beliefs, attitudes and principles. The performed study shows that the respondents, demonstrating the ability to establish quickly actor-actor contacts, can understand and accept their own aspirations and feelings, their own emotions, including negative ones, without a need for feedback, without much concern for emotional reactions of others. It is noticed the lack of harmonization of the students' self-actualization process and underdevelopment of their ability to constructive self-realization. The expediency of development and introduction of effective techniques for personal potential development, awareness of Self for self-realization and psychological well-being is substantiated.

Key words: personality, personal development, self-attitude, self-actualization, self-realization.

\section{Вступ}

Динамізм і змінюваність сучасного світу, його глобалізація, постійне оновлення інформації, знань висуває у якості провідної ідеї сучасної освіти максимальне наближення навчання i виховання особистості до їі індивідуальних особливостей та обдарувань, актуалізує проблеми дослідження розвитку самосвідомості особистості, формування ціннісного ставлення до самої себе. Такий підхід дасть змогу «пізнати себе, розвинути себе на основі власних здібностей і у дорослому віці максимально самореалізуватися. Останнє є неодмінною умовою особистого щастя й динамічного та несуперечливого суспільного прогресу» (Кремень, 2017: 7). 
У психологічних дослідженнях самореалізація, самоактуалізація розглядаються центральним аспектом розвитку особистості. А. Маслоу визначав самоактуалізацію не тільки як «кінцевий пункт нашої подорожі, але і як саму подорож», іiі рушійну силу (Maslow, 1993). Самоактуалізація, за К. Роджерсом, - це розкриття природного особистісного потенціалу, актуалізація вродженої тенденції до зростання й розвитку особистості відповідно до того, якою ця особистість має природно бути, в сприятливих і необхідних для цього умовах (Rogers, 1980). Виходячи з постулатів теорії самодетермінації Десі та Райана, у якій «Я» розглядається «як центр досвіду та як ініціатор і регулятор вольової поведінки» (Ryan \& Deci, 2017), Grund, Fries \& Rheinberg стверджують, що людина за своєю сутністю прагне внутрішньособистісної і соціальної цілісності, задоволення своїх вроджених психологічних потреб у автономії, компетентності й взаємозв'язках з іншими людьми. Автори наголошують на необхідності розвитку мотиваційної компетентності як важливої передумови саморегуляції для ефективної, успішної життєдіяльності (Grund, Fries \& Rheinberg, 2018).

Сучасні зарубіжні дослідження саморегуляції центруються на вивченні того, як люди керують своїми мотиваційними станами для досягнення значущих для них цілей. Здійснювалось вивчення взаємозв'язків самодетермінації, компетентності й цінностей самореалізації з «суб’єктивним досвідом внутрішньої мотивації» у студентів-магістрантів коледжу (Waterman, Schwartz \& Goldbacher, 2003); впливу чинників самодетермінації (автономії, самореалізаціï, «розширення психологічних можливостей») у випускників шкіл на їх подальшу професійну життєдіяльність (Shorgen, Jaehoon \& Panko, 2016); у концептуальній структурі процесу самореалізації у студентів розглянуто процеси постановки цілей, самоефективності й мотиваційні переконання як потенціал для інформаційної вікової парадигми освіти (Huh \& Reigeluth, 2017). Один із нових напря- 
мів фокусується на дослідженні переконань людей стосовно їх власної мотивації (тобто, метамотиваційних знань), їх адаптивної функції, а також впливу цих знань на вибір стратегї̈ регулювання (Scholer, Miele \& Murayama, 2018).

Вітчизняними вченими у парадигмі самодетермінації розвитку особистості досліджено психологічний потенціал самореалізації (Maksymenko \& Serdiuk, 2016), ціннісні аспекти самореалізації особистості (Пенькова, 2018), концептуальні парадигми самоефективності (Дригус, 2017), прояви життєстійкості особистості (Chykhantsova, 2018), розглянуто технології активізації життєвих перспектив у діалогово-феноменологічному підході (Володарська, 2017), а також висвітлено мотивацію до творчої самореалізації у процесі формування толерантного освітнього середовища (Яланська \& Атаманчук, 2017). Дослідники наголошують, що реалізація особистісного потенціалу, "особистісного проекту» (Чепелєва, 2017) неможлива без адекватного ставлення людини до оточуючого світу й до самої себе. Власне, саме позитивне самоставлення особистості поряд із її особистісними домаганнями і перспективами, автономією, самоефективністю виступає показником самодетермінованої особистості.

Самоставлення як складна багаторівнева емоційноціннісна система проходить в онтогенезі певні етапи розвитку на основі активного засвоєння інформації про власне «Я», інтегруючи й ієрархізуючи її, збільшуючи міру самореалізованості особистості. Н. І. Сарджвеладзе розглядав самоставлення як один із видів установки, що має трикомпонентну структуру, яка включає когнітивний, емоційний і конативний компоненти. Учений наголошував, що оскільки час є особливим виміром особистості, за яким вирізняються актуальне «Я» («я тут і тепер»), ретроспективне «Я» ( «я у минулому») і проспективне «Я» ( я у майбутньому»), то виокремлюються і «можливі способи часового конституювання самоставлення» (Сарджвеладзе, 2007: 195-196). Такими часовими вимірами самоставлення він 
визначив адаптацію до самого себе (самопристосування), перетворення соціального середовища і самоперетворення. У структурі джерел самоставлення Н. I. Сарджвеладзе виокремлював біологічний, психологічний і соціальний компоненти. До структурних одиниць біологічного компонента вчений включав ставлення до своєї зовнішності, до анатомічних і біохімічних особливостей, до функціонально-фізіологічних можливостей. Структурними одиницями психологічного компонента, на думку Н. I. Сарджвеладзе, виступають ставлення індивіда до своїх сенсомоторних особливостей, до інструментальних можливостей, до інтелектуальних здібностей, до своїх емоційних особливостей і вольових якостей; до самого себе як до неповторної особистості. До структури соціального компонента входять такі одиниці, як ставлення індивіда до свого соціального становища, ставлення до нього інших та їхні очікування, ставлення до самого себе як носія певних соціальних норм і цінностей. Самоставлення виконує певні функції, серед яких: функція «дзеркала» (відображення себе); самовираження та самореалізації; збереження внутрішньої стабільності й континуальності «Я»; саморегуляції й самоконтролю; психологічного захисту і функція інтракомунікації (Сарджвеладзе, 1989).

Як важливий компонент структури самосвідомості самоставлення є одним із чинників формування «Я» особистості, що «інтегрує всі їі життєві вияви, а також дозволяє особистості розглядати себе зсередини, спостерігати, усвідомлювати та змінювати себе, регулювати свою життєдіяльність» (Савчин, 2002: 216). На основі несуперечливого самосприйняття, співставлення зі сприйняттям себе іншими людьми, їх емоційним ставленням, а також самоставлення, що глибоко переживається, будується «Я-концепція» як «всезагально організований патерн аутоперцепції» (Савчин, 2002: 217).

Тобто, самоставлення є відображенням інтегрованості та безконфліктності певної смислової структури, яка за- 
лежно від змісту і цілісності виражається в різних формах поведінки (Сердюк, 2012: 154). Самоставлення людини значною мірою визначає оцінку навколишньої дійсності, формування уявлень про світ і себе самого, забезпечує прогнозування своєї соціальної ефективності та ставлення до себе оточення, регулює міжособистісні взаємини, постановку і досягнення цілей, впливає на процеси саморозвитку та самореалізації $\mathrm{i}$, поряд із соціальним статусом i установкою особистості до зовнішнього світу, представляє зміст системи «особистість - соціальне середовище» й є однією зі структурних одиниць диспозиційного ядра особистості (Serdiuk, 2014). Власне, саме позитивне самоставлення особистості разом із їі системою ціннісних орієнтацій, автономією, самоефективністю та перспективою майбутнього виступає показником самоактуалізованої особистості, показує, «наскільки людина є суб’єктом, автором власного життя, наскільки вона сама детермінує власну життедіяльність» (Maksymenko \& Serdiuk, 2016: 94).

У сучасних наукових розвідках питання самоставлення та його впливу на процеси самоактуалізації, самореалізації вивчаються у різних сферах життєдіяльності. Так, розглянуто позитивне ставлення до себе компонентом багатовимірної інтеграційної моделі психологічного благополуччя особистості (Карсканова, 2012); проаналізовано творчі прояви особистості в якості детермінант і умов формування самоставлення, оскільки в них відображається особистість як суб'єкт діяльності на шляху розкриття власного потенціалу й самореалізації (Колодяжна, 2013: 203); доведено, що позитивне самоставлення, самоприйняття, формування цілісного образу «Я» і адекватної самооцінки, розвиток емоційної саморегуляції, впевненості у собі слугують ефективним засобом формування психологічної здатності до конструктивного самоствердження особистості (Свченко, 2013); висвітлено особливості самоставлення комп'ютерних гравців, а також напрями корекційної ро- 
боти для створення позитивної «Я-концепції» у групах студентів залежно від їх ігрових переваг (Chaika, 2016); 3'ясовано, що емоційно-ціннісне ставлення до себе як до суб'єкта конкретної професійної діяльності, до власного «Я», своїх професійних якостей і результатів професійної діяльності є центральним компонентом професійної самосвідомості особистості та сприяє її самореалізації у діяльності (Онуфрієва, 2018).

У студентської молоді в період професійної підготовки у закладі вищої освіти виникають «біфуркаційні періоди», що спричиняють «суттєві зміни в осмисленні свого життєвого шляху, його цілей і смислу, порушуючи цілісність системи ставлень особистості, позитивного самосприйняття, статусного положення та міжособистісної взаємодії (Сердюк, 2012: 203). Водночас цей життєвий етап є надзвичайно значущим у становленні особистості, саме у цей час створюються умови для найповнішого розкриття потенційних можливостей, активно відбуваються процеси саморозвитку й самотворення. Тому актуальним $\epsilon$ вивчення особливостей самоставлення студентів, а також взаємозв'язків показників самоставлення й інших компонентів у структурі самодетермінації особистісного розвитку в цьому віковому періоді.

Мета статті - здійснити аналіз результатів емпіричного дослідження особливостей ставлення до себе у групах студентів із високим і низьким рівнем самодетермінації, а також взаємозв'язків показників самоставлення і самоактуалізації у студентів.

\section{Завдання статті}

1. Виявити особливості співвідношення вираженості рівнів самоставлення у студентів із високою та низькою самодетермінацією.

2. Проаналізувати взаємозв'язки показників самоставлення та самоактуалізації як компонентів самодетермінації особистості у студентів. 


\section{Методи та методики дослідження}

У дослідженні брали участь студенти закладів вищої освіти у кількості 235 осіб. У комплексному дослідженні за попередньо встановленими рівнями сформованості автономії, самореалізації, життєвих перспектив уся вибірка була поділена на дві групи: особи з високою самодетермінацією та особи з низькою самодетермінацією.

Для вивчення особливостей ставлення до себе студентів застосовувався тест-опитувальник самоставлення В. В. Століна, С. Р. Пантілєєва (Столин \& Пантилеев, 1988). Опитувальник дає змогу виявити три рівні самоставлення за ступенем узагальненості: глобальне самоставлення; самоставлення, диференційоване за самоповагою, аутосимпатією, самоінтересом і очікуваним ставленням інших; рівень конкретних дій (готовності до них) щодо свого «Я» (самовпевненість, ставлення інших, самоприйняття, самокерівництво і самопослідовність, самозвинувачення, інтерес до себе, саморозуміння).

Феномен самоактуалізації досліджувався з використанням самоактуалізаційного тесту, побудованого на принципах опитувальника особистісних орієнтацій Е. Шострома (Personal Orientation Inventory) в адаптації Ю. Є. Альошиної, Л. Я. Гозмана, М. В. Загіки і М. В. Кроза (Алешина, Гозман, Загика \& Кроз, 2018). Опитувальник розроблено на засадах теорії самоактуалізації А. Маслоу, концепцій психологічного сприйняття часу і часової орієнтації суб'єкта Ф. Перлза і Р. Мея, ідей К. Роджерса й інших теоретиків екзистенціально-гуманістичного напряму в психології. Базові шкали тесту («компетентність у часі» $\mathrm{i}$ «підтримка») вимірюють глобальні характеристики самоактуалізації. Дванадцять додаткових шкал утворюють шість блоків: блок цінностей (шкали ціннісних орієнтацій і гнучкості поведінки), блок почуттів (шкали сенситивності до себе i спонтанності), блок самосприйняття (шкали самоповаги i самоприйняття), блок концепції людини (шкали уявлень про природу людини і синергії), блок міжособистісної чут- 
ливості (шкали прийняття агресії і контактності), блок ставлення до пізнання (шкали пізнавальних потреб і креативності).

Обробка результатів експериментального дослідження здійснювалася за допомогою програми для статистичної обробки даних SPSS Statistics 21.0. Порівняльний аналіз вибіркових середніх за t-критерієм Стьюдента показав статистично значущі відмінності за виокремленими показниками.

\section{Результати та дискусії}

Аналізуючи дані щодо співвідношення показників самоставлення та відсоткової вираженості рівнів самоставлення, наведені у табл. 1, можна зробити висновок, що при загалом високих показниках інтегрального самоставлення у значної частини студентів, особливо з групи з низькою самодетермінацією, компоненти самоставлення сформовані на низькому рівні. Так, більш ніж у третини таких осіб виявлено низький рівень показників аутосимпатії, самовпевненості, від чверті до третини - низький рівень показників самоінтересу, самоповаги, саморозуміння, самопослідовності. Слід зауважити, що у групі низькодетермінованих студентів рівень сформованості показника «ознака не виражена» є вищим як порівняно з групою високодетермінованих, так і з усією вибіркою, для практично усіх показників (окрім самоприйняття). Привертає увагу, що високих показників самоповаги і самовпевненості у групі осіб із низькою детермінацією виявилося практично вдвічі менше, порівняно з групою високодетермінованих: 46,9\% і 49,6\% та 77,8\% і 83,3\% відповідно. Стосовно показників «очікуване ставлення інших» - студенти з низькою самодетермінацією виявили найвищий відсоток низького їх рівня як за диференційованою шкалою, так і за шкалою установок: по 34,4\% . При цьому за показником «самозвинувачення» ця група студентів виявила найбільший відсоток низького рівня $(59,4 \%$, порівняно з 55,6\% у групі 
високодетермінованих і 58\% за вибіркою загалом). Тобто, позитивно сприймаючи себе загалом (високий рівень самоприйняття - 62,5\%), такі студенти залежні від оцінок оточуючих, очікуючи негативного ставлення до себе, що, відповідно, призводить до «включення» механізмів захисту свого «Я». Вони можуть мати проблеми з усвідомленням своїх потенціальних можливостей і життєвих перспектив.

Таблиия 1

Рівні вираженості показників самоставлення у студентів із високою та низькою самодетермінацією, \%

\begin{tabular}{|c|c|c|c|c|c|c|c|c|c|}
\hline \multirow{3}{*}{$\begin{array}{c}\text { Компоненти } \\
\text { самоставлення }\end{array}$} & \multicolumn{3}{|c|}{ Уся вибірка } & \multicolumn{3}{|c|}{$\begin{array}{c}\text { Особи з високою } \\
\text { самодетер- } \\
\text { мінацісю } \\
\end{array}$} & \multicolumn{3}{|c|}{$\begin{array}{c}\text { Особи з низькою } \\
\text { самодетер- } \\
\text { мінацісю }\end{array}$} \\
\hline & \multicolumn{9}{|c|}{ Рівень вираженості } \\
\hline & HB & B & ЯВ & HB & B & ЯВ & HB & B & ЯВ \\
\hline $\begin{array}{l}\text { Інтегральне } \\
\text { самоставлення }\end{array}$ & 6 & 32 & 62 & 5,6 & 16,7 & 77,8 & 6,3 & 40,6 & 53,1 \\
\hline Самоповага & 16 & 26 & 58 & 5,6 & 16,7 & 77,8 & 21,9 & 31,3 & 46,9 \\
\hline Аутосимпатія & 26 & 18 & 56 & 16,7 & 22,2 & 61,1 & 31,3 & 15,6 & 53,1 \\
\hline $\begin{array}{l}\text { Очікуване } \\
\text { ставлення інш }\end{array}$ & 32 & 54 & 14 & 27,8 & 50,0 & 22,2 & 34,4 & 56,3 & 9,4 \\
\hline Самоінтерес & 22 & 16 & 62 & 11,1 & 16,7 & 72,2 & 28,1 & 15,6 & 56,3 \\
\hline Самовпевненість & 26 & 18 & 56 & 11,1 & 5,6 & 83,3 & 34,4 & 25,0 & 49,6 \\
\hline Ставлення інших & 32 & 50 & 18 & 27,8 & 50,0 & 22,2 & 34,4 & 50,0 & 15,6 \\
\hline Самоприйняття & 18 & 14 & 68 & 5,6 & 16,7 & 77,8 & 12,5 & 25,0 & 62,5 \\
\hline $\begin{array}{l}\text { Самокерівництво, } \\
\text { самопослідовність }\end{array}$ & 24 & 24 & 52 & 16,7 & 27,8 & 55,6 & 28,1 & 21,9 & 50,0 \\
\hline Самозвинувачення & 58 & 16 & 26 & 55,6 & 27,8 & 16,7 & 59,4 & 9,4 & 31,3 \\
\hline Інтерес до себе & 20 & 16 & 64 & 11,1 & 22,2 & 66,7 & 25,0 & 12,5 & 62,5 \\
\hline Саморозуміння & 30 & 22 & 48 & 38,9 & 11,1 & 50,0 & 25,0 & 28,1 & 46,9 \\
\hline
\end{tabular}

Прилітка. НВ - ознака не виражена; В - ознака виражена; ЯВ - ознака яскраво виражена.

Стосовно групи високодетермінованих студентів слід зазначити, що у середньому близько $70 \%$ виявили на рів- 
ні «яскраво виражено» показники глобального самоставлення, самоповаги, аутосимпатії, самоінтересу, самовпевненості, самоприйняття, що свідчить про їх прийняття себе, впевненість у можливості контролювати своє життя, високу оцінку своїх інтенцій. Хоча при цьому можна говорити про недиференційоване емоційно позитивне самосприйняття, у яке не включений когнітивний компонент, оскільки саме у цій групі осіб найвищий, порівняно з групою несамодетермінованих і з вибіркою загалом, відсоток низького рівня показника саморозуміння $(38,9 \%, 25 \%$ i 30\% відповідно).

Отже, аналіз вивчення самоставлення студентів дає підстави стверджувати, що у групах студентів із високою та низькою самодетермінацією структура самоставлення відрізняється вираженістю його компонентів. Проте для досліджуваних характерні загалом високі показники інтегрального самоставлення й високі та середні показники диференційованих шкал і шкал установок.

Аналіз кореляційних зв'язків показників самоставлення та саморозвитку і самореалізації особистості, що вивчалися за допомогою Самоактуалізаційного тесту (CAT), показав таке (табл. 2). По одному вираженому кореляційному зв'язку виявлено за шкалами гнучкості поведінки із самоприйняттям $\left(0,396^{* *}\right)(\mathrm{p} \leq 0,01)$, сенситивності до себе зі ставленням інших $\left(0,392^{* *}\right)(\mathrm{p} \leq 0,01)$, пізнавальних потреб з інтересом до себе як за диференційованою шкалою самоставлення $\left(0,381^{* *}\right)(\mathrm{p} \leq 0,01)$, так і за шкалою установок $\left(0,364^{* *}\right)(\mathrm{p} \leq 0,01)$. Останнє є підтвердженням зробленого вище висновку про високу готовність студентів до самопізнання, їх чутливість до власних думок і почуттів. Шкала самоприйняття САТ пов'язана менш вираженими кореляційними зв'язками з близькими за змістом показниками самоставлення: самоповагою $\left(0,33^{*}\right)(\mathrm{p} \leq 0,05)$, аутосимпатією $\left(0,338^{*}\right)(\mathrm{p} \leq 0,05)$, самовпевненістю $\left(0,287^{*}\right)$ $(\mathrm{p} \leq 0,05)$, саморозумінням $\left(0,348^{*}\right)(\mathrm{p} \leq 0,05)$. 


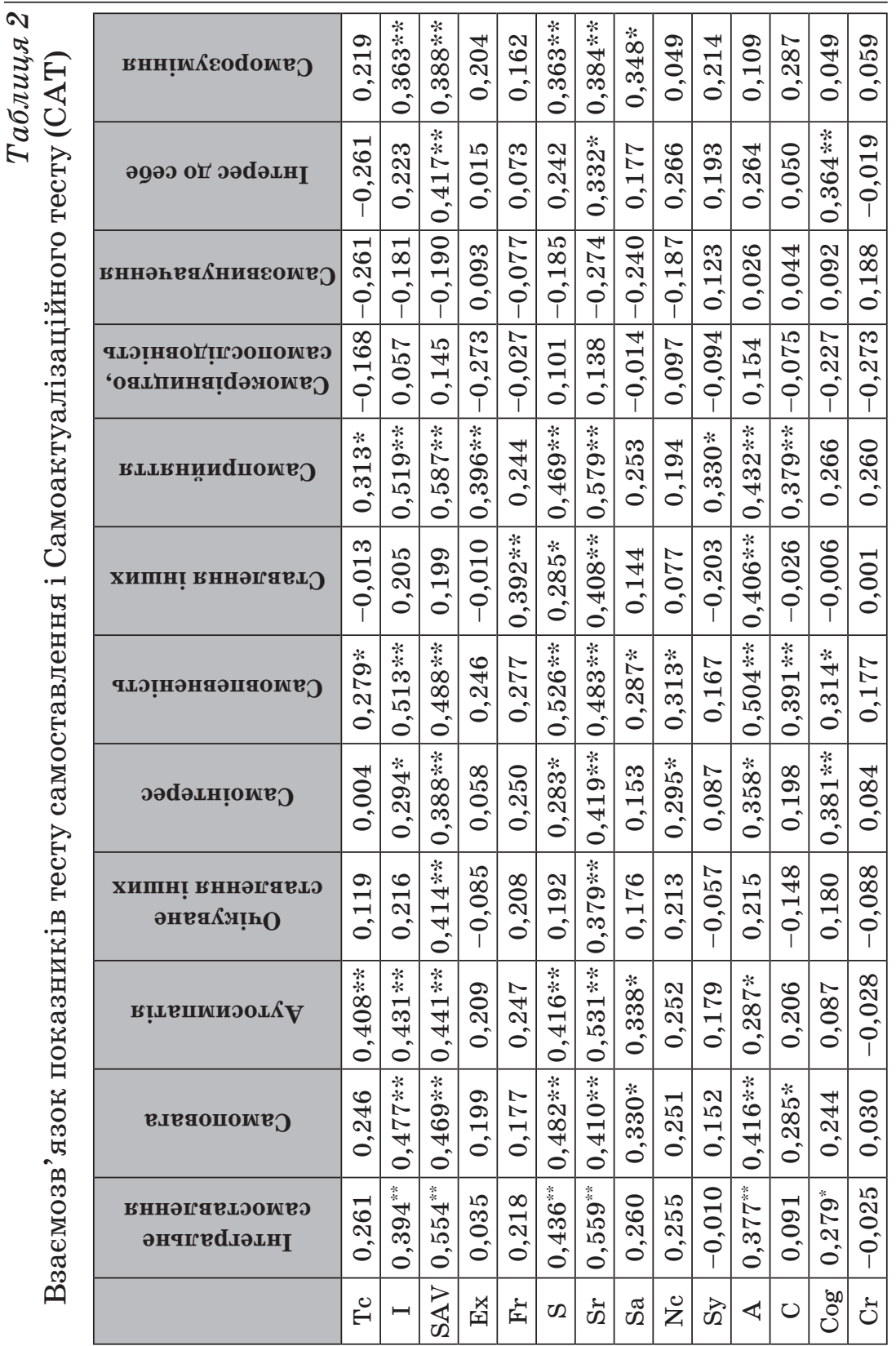


Прилітка. Тс - шкала компетентності в часі; I - шкала підтримки; SAV - шкала ціннісних орієнтацій; Ex - шкала гнучкості поведінки; $\mathrm{Fr}$ - шкала сенситивності до себе; $\mathrm{S}$ - шкала спонтанності; $\mathrm{Sr}$ - шкала самоповаги; $\mathrm{Sa}$ - шкала самоприйняття; Nc - шкала уявлень про природу людини; Sy - шкала синергії; A - шкала прийняття агресії; C - шкала контактності; Cog шкала пізнавальних потреб; $\mathrm{Cr}$ - шкала креативності.

** - кореляція значуща на рівні 0,01 (2-сторон.); * - кореляція значуща на рівні 0,05 (2-сторон.).

Відзначимо відсутність, з одного боку, значущих кореляційних зв'язків із показниками САТ таких показників самоставлення, як самокерівництво, самопослідовність і самозвинувачення, а з іншого - відсутність зв'язків із показниками самоставлення таких шкал САТ, як уявлення про природу людини, шкали синергії та креативності.

Подальший ранговий аналіз даних свідчить, що перше рангове місце за кількістю виявлених кореляційних зв'язків із показниками самоставлення (окрім указаних вище показників самопослідовності й самозвинувачення) має шкала самоповаги: значущі кореляційні зв'язки з усіма десятьма показниками самоставлення. Друге рангове місце посідають шкали ціннісних орієнтацій і спонтанності (по вісім кореляційних зв'язків), третє - шкали підтримки й прийняття агресії (по сім кореляційних зв'язків). Не виявлено кореляцій за вказаними шкалами із показниками очікуваного ставлення інших, інтересу до себе, а також - в останньому випадку - саморозумінням. Четверте рангове місце посідає шкала контактності (чотири кореляційних зв'язки) і п'яте - шкала компетентності в часі (три кореляційних зв'язки).

Аналіз взаємозв'язків показників самоставлення й окремих аспектів (блоків) самоактуалізації дав змогу виявити такі тенденції (рис. 1). Стосовно блоку цінностей (шкали ціннісних орієнтацій і гнучкості поведінки) можна констатувати, що особи з високими показниками інтегрального самоставлення поділяють цінності самоактуалі- 

зованої особистості, при цьому, однак, мають труднощі з їх реалізацією, здатністю швидко й адекватно реагувати на ситуацію, що змінюється.

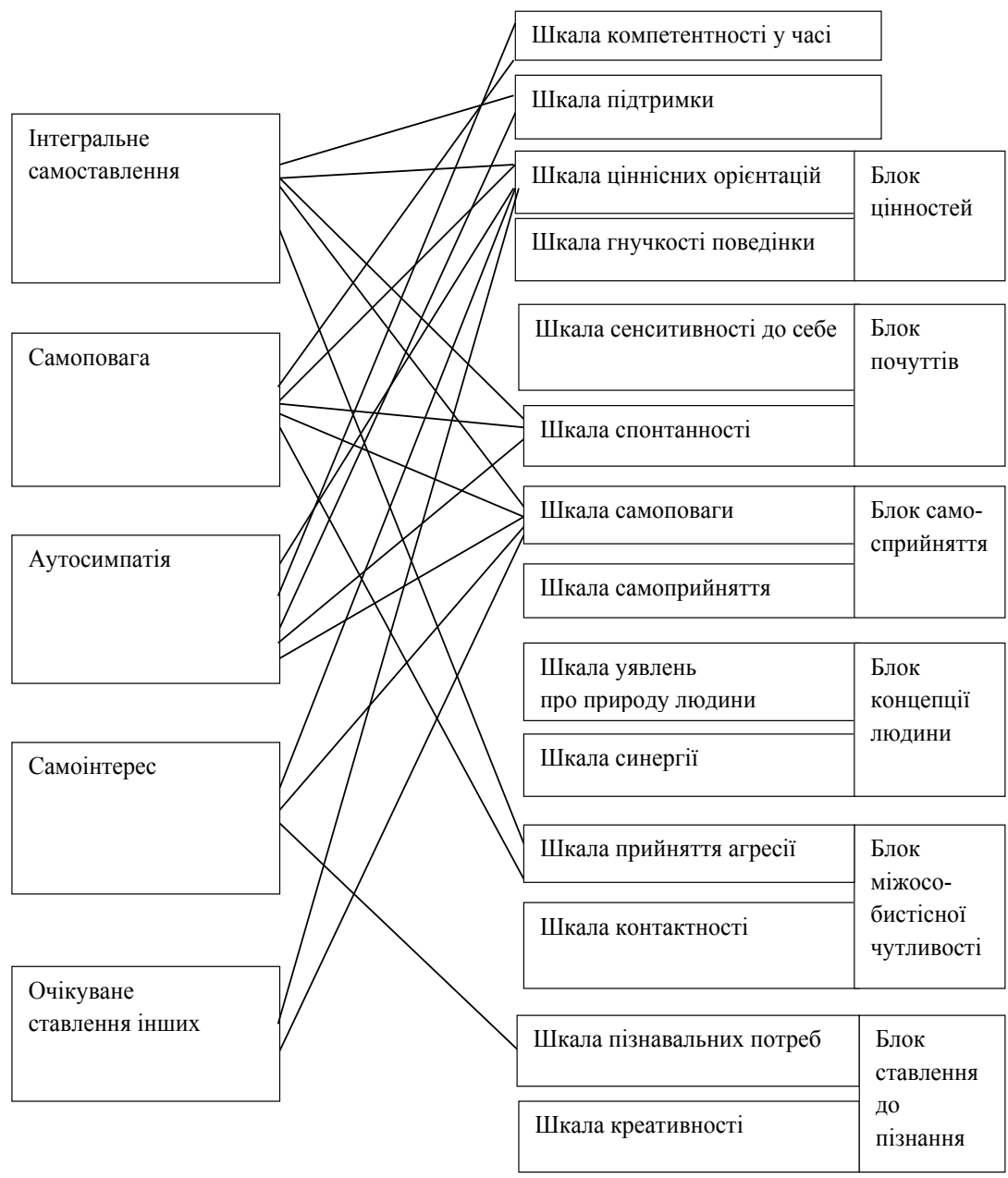

Puc. 1. Модель зв' язків показників глобального самоставлення, самоставлення, диференційованого за самоповагою, аутосимпатією, самоінтересом й очікуваним ставленням інших, і шкал самоактуалізації 
Значна кількість кореляційних зв'язків показників самоставлення зі шкалою спонтанності з блоку почуттів свідчить про те, що досліджувані схильні безпосередньо висловлювати свої почуття й демонструвати емоційні стани, але недостатньо усвідомлюють і рефлексують їх. Аналіз зв'язків змістово подібних показників самоставлення і шкал блоку самосприйняття дає підстави для висновку про те, що поважаючи й цінуючи себе, свої позитивні якості, досліджувані, з одного боку, почуваються залежними від оцінок своїх чеснот з боку оточуючих, а з іншого - намагаючись захистити своє позитивне самоставлення, можуть удаватися до ігнорування, відкидання думок і оцінок інших людей.

Стосовно міжособистісних ставлень (блок міжособистісної чутливості) можна стверджувати: особи з високою самовпевненістю й самоприйняттям більш схильні до встановлення глибоких і тісних контактів, приймаючи навіть свої негативні емоційні прояви щодо інших як природні й допустимі. Незначна кількість кореляційних зв'язків показників самоставлення та показників шкал блоку ставлення до пізнання, а також відсутність зв'язків зі шкалами блоку концепції людини свідчить про те, що прагнення набувати знань про навколишній світ, відкритість до цих знань не є домінуючими в актуальному світосприйнятті студентів, у них ще не сформоване цілісне концептуальне уявлення про людську природу, про, власне, свою природу, вони не володіють належною мірою інструментарієм саморозвитку. Подібні висновки зроблені у дослідженні С. Максименка та Л. Сердюк про недостатню сформованість у досліджуваних студентів таких особистісних якостей, як орієнтація в часі, що означає недостатню узгодженість подій життя, впевненості у своїх силах і можливостях, прагнення до набуття знань про навколишній світ. Водночас дослідники наголошують, що такі низькі показники вказують саме на особистісні ресурси і потенціал самореалізації особистості (Maksymenko \& Serdiuk, 2016). Такі дані ко- 
релюють також із результатами дослідження О. I. Моткова про деяку дисгармонійність процесів самоактуалізації у цьому віці. На думку дослідника, баланс цінностей досягається поступово з віком, коли долається розрив між силою базового прагнення до свободи, самостійності й мірою його реалізації у поведінці та діяльності (Мотков, 2007). Крім того, ми солідаризуємося з тезою О. І. Моткова про те, що розвиток особистості повинен першочергово орієнтуватися не на досягнення максимальних успіхів у реалізації призначення, самоздійсненні «за будь-яку ціну», а на досягнення гармонійного процесу самоактуалізації, на розвиток «Б-цінностей» - прагнення до істини, добра, краси, гармонії, всебічності тощо (Maslow, 1993).

\section{Висновки}

Аналіз даних дослідження особливостей самоставлення студентів дає підстави констатувати, що їх ставлення до себе має виражений позитивний емоційний модус. Можна зробити висновок про наявність взаємозв' язків показників самоставлення й самореалізації особистості. Зафіксовано, що висока позитивна оцінка досліджуваними самих себе пов'язана зі здатністю цінувати свою гідність, поважати себе, безпосередньо і спонтанно виражати свої почуття, демонструвати емоції, намаганням бути відносно незалежним у своїх вчинках, прагненням керуватися в житті власними цілями, переконаннями, установками і принципами. Демонструючи здатність до спілкування, швидкого встановлення суб'єкт-суб'єктних контактів, вони виявляють здатність усвідомлювати і приймати власні прагнення й почуття, власні емоційні, у тому числі негативні, прояви, не відчуваючи при цьому потреби у зворотному зв'язку, не надто переймаючись емоційними реакціями оточуючих. Власне, природа людини, концептуально-філософське сприйняття світу і людей поки що не присутне в актуальному шарі самосвідомості досліджуваних, оскільки шкали блоку «концепція людини» не виявили значущих кореля- 
ційних зв' язків із показниками самоставлення. Зауважено недостатню гармонійність процесу самоактуалізації у студентської молоді, розвитку здатності до конструктивної самореалізації.

У цьому зв'язку в якості подальших перспектив дослідження надзвичайно значущою видається розробка і впровадження ефективних технологій сприяння розвитку особистісного потенціалу, усвідомлення себе, своїх життєвих цілей, перспектив, цінностей для самореалізації та психологічного благополуччя особистості.

\section{Література}

Алешина Ю. Е., Гозман Л. Я., Загика М. В., Кроз М. В. Самоактуализационный тест - CAT. Психологос. 2018. URL : https://www. psychologos.ru/articles/view/samoaktualizacionnyy-test---sat.

Бодалев А. А., Столин В. В., Аванесов В. С. Общая психодиагностика. Санкт-Петербург : Речь, 2000. 440 с.

Володарська Н. Д. Технології активізації процесу самодетермінації розвитку особистості: діалогово-феноменологічний підхід. Актуальні проблеми психологї: Збірник наукових пращь Інституту психології імені Г. С. Костюка НАПН України. Київ - Житомир : Вид-во ЖДУ імені I. Франка, 2017. Т. VI. Вип. 13. С. 32-38.

Дригус М. Т. Концептуальні парадигми самоефективності особистості. Актуальні проблеми психології: Збірник наукових пращь Інституту психологї імені Г. С. Костюка НАПН України. Київ : Видавництво «Фенікс», 2017. Т. ХІІ. Вип. 23. С. 88-97.

Євченко I. М. Психологічні засади формування у студентів здатності до самоствердження: автореф. дис. ... канд. психол. наук: спец. 19.00.07 «Педагогічна та вікова психологія». Одеса, 2013. 18 с.

Карсканова С. В. Психологічне благополуччя особистості як основа фахового зростання: автореф. дис. ... канд. психол. наук: спец. 19.00.01 «Загальна психологія, історія психології. Київ, 2012.18 с.

Колодяжна А. В. Умови та фактори формування самоставлення. Актуальні проблеми психологї / За ред. С. Д. Максименка. Київ : Видавництво «Фенікс», 2013. Т. 12. Вип. 16. С. 197-204.

Мотков О.И. О парадоксах процесса самоактуализации личности. Природа личности: сущность, структура и развитие. Москва : Воскресенская типография, 2007. 248 с.

Наукове забезпечення розвитку освіти в Україні: актуальні проблеми теорії і практики (до 25-річчя НАПН України). Збірник наукових праць. Київ : Видавничий дім «Сам», 2017. 400 с. 
Onufriieva L. A. The theoretical and methodological analysis of Me-professional image as a component of future professionals' Me-concept. Проблели сучасної психологї: Збірник наукових праць Кал'янець-Подільського національного університету ілені Івана Огієнка, Інституту психології ілені Г. С. Костюка НАПН України / За наук. ред. С. Д. Максименка, Л. А. Онуфрієвої. Кам'янець-Подільський : Аксіома, 2018. Вип. 39. С. 195-205. DOI 10.32626/2227-6246.2018-39.195-205.

Пенькова О. І. Ціннісні аспекти самореалізації особистості. Актуальні проблели психологї: Збірник наукових праць Інституту психологї ілені Г. С. Костюка НАПН України. Київ - Житомир : Вид-во жҐДУ імені І. Франка, 2018. Т. VI. Вип. 14. С. 201-207.

Савчин I. М. Самосвідомість школяра як предмет професійної уваги вчителя. Проблели загальної та педагогічної психологї: Збірник наукових праць Інституту психологї̈ іл. Г. С. Костюка АПН Украӥни. Київ, 2002. Т. IV, ч. 5. С. 215-219.

Сарджвеладзе Н. И. Личность и ее взаимодействие с социальной средой. Тбилиси : Мецниереба, 1989. 204 с.

Сарджвеладзе Н. И. Самоотношение личности. Психология салосознания. Самара : Издательский дом «БАХРАХ-М», 2007. С. 174-207.

Сердюк Л. 3. Психологія мотивації учіння майбутніх фахівців: системно-синергетичний підхід. Київ : Університет «Україна», 2012. $323 \mathrm{c}$.

Столин В. В., Пантилеев С. Р. Опросник самоотношения. Практикул по психодиагностике: психодиагностические лмтериаль. Москва : Изд-во МГУ, 1988. С. 123-130.

Яланська С. П., Атаманчук Н. М. Психологія формування толерантного середовища в умовах нової української школи. Наука і освіта. Психологія. 2017. № 1. С. 71-75. DOI http://doi.org/10.24195/ 2414-4665-2017-1-12.

Chaika, G. (2016). Characteristics of self-concept of computer gamers. Social Welfare: Interdisciplinary Approach, 6 (1), 40-51. Retrieved from http://dx.doi.org/10.21277/sw.v1i6.235.

Chykhantsova, O. (2018). Features of Demonstration of Hardiness' Components of Personality. Science and Education, a New Dimension. Pedagogy and Psychology, VI (65), Issue 155, 58-60. Budapest. Retrieved from http://lib.iitta.gov.ua/710360/.

Grund, A., Fries, S., \& Rheinberg, F. (2018). Know Your Preferences: SelfRegulation as Need-Congruent Goal Selection. Review of General Psychology, 22, Issue 4, 437-451. Retrieved from https://doi.org/ $10.1037 / \mathrm{gpr} 0000159$.

Huh, Y., \& Reigeluth, C. M. (2017). Self-Regulated Learning: The Continuous-Change Conceptual Framework and a Vision of New Paradigm, 
Technology System, and Pedagogical Support. Journal of Educational Technology Systems, 46, Issue 2, 191-214. Retrieved from https://doi.org/10.1177/0047239517710769.

Maksymenko, S., \& Serdiuk, L. (2016). Psychological Potential of Personal Self-realization. Social Welfare: Interdisciplinary Approach, 6 (1), 92-100. Retrieved from http://dx.doi.org/10.21277/sw.v1i6.244.

Maslow, A. (1993). The Farther Reaches of Human Nature. New York : Penguin.

Rogers, C. A (1980). Way of Being. New York: Houghton Mifflin.

Ryan, R. M., \& Deci E. L. (2017). Self-Determination Theory: Basic psychological needs in motivation, development and wellness. New York, NY : Guilford Press Publishing.

Scholer, A. A., Miele, D. B., \& Murayama, K. (2018). New Directions in Self-Regulation: The Role of Metamotivational Beliefs. Current Directions in Psychological Science, 27, Issue 6, 437-442. Retrieved from https://doi.org/10.1177/0963721418790549.

Serdiuk, L. (2014). Personal Modus of Future Specialists' Self-Realization. Social Welfare: Interdisciplinary Approach, 4 (1), 71-80.

Shorgen, K. A., Jaehoon, L., \& Panko, P. (2016). An Examination of the Relationship between Postschool Outcomes and Autonomy, Psychological Empowerment, and Self-Realization. The Journal of Special Education, 51, Issue 2, 115-124. Retrieved from http://doi.org/ $10.1177 / 0022466916683171$.

Waterman, A. S., Schwartz, S. J., \& Goldbacher, E. (2003). Predicting the Subjective Experience of Intrinsic Motivation: The Roles of Self-Determination, the Balance of Challenges and Skills, and SelfRealization Values. Personality and Social Psychology Bulletin, 29, Issue 11, 1447-1458. Retrieved from https://doi.org/10.1177/ 0146167203256907.

\section{References}

Aleshina, Ju. E., Gozman, L. Ja., Zagika M. V., \& Kroz, M. V. (2018). Samoaktualizatsionnyj test - SAT [Self-actualization test - SAT]. Psihologos - Psychologos. Retrieved from https://www.psychologos.ru/ articles/view/samoaktualizacionnyy-test---sat [in Russian].

Bodalev, A. A., Stolin, V. V., \& Avanesov, V. S. (2000). Obshchaja psihodiagnostika [General Psychodiagnosis]. Sankt-Peterburg : Rech' [in Russian].

Volodarska, N. D. (2017). Tekhnolohii aktyvizatsii protsesu samodeterminatsii rozvytku osobystosti: dialohovo-fenomenolohichnyi pidkhid [Technologies of Activation of the Process of Self-Determination of Personality Development: Dialogue-Oriented and Phenomenological Approach]. Aktualni problemy psykholohii - Actual problems of 
psychology, VI, 13, 32-38. Kyiv - Zhytomyr : Vyd-vo ZhDU imeni I. Franka [in Ukrainian].

Dryhus, M. T. (2017). Kontseptualni paradyhmy samoefektyvnosti osobystosti [Conceptual paradigms of self-efficacy of personality]. Aktualni problemy psykholohii - Actual problems of psychology: Collection of research papers of G. S. Kostiuk Institute of Psychology of NAES of Ukraine, XVII, 23, 88-97. Kyiv : Vydavnytstvo «Feniks» [in Ukrainian].

Yevchenko, I. M. (2013). Psykholohichni zasady formuvannia u studentiv zdatnosti do samostverdzhennia [Psychological principles of formation of students' ability to self-affirmation]. Extended abstract of candidate's thesis. Odesa [in Ukrainian].

Karskanova, S. V. (2012). Psykholohichne blahopoluchchia osobystosti yak osnova fakhovoho zrostannia [Psychological well-being of the personality as the basis of professional growth]. Extended abstract of candidate's thesis. Kyiv [in Ukrainian].

Kolodiazhna, A. V. (2013). Umovy ta faktory formuvannia samostavlennia [Conditions and factors of forming self-attitude]. S. D. Maksymenko (Ed.). Aktualni problemy psykholohii-Actual problems of psychology, $X I I, 16,197-204$. Kyiv : Vydavnytstvo «Feniks» [in Ukrainian].

Motkov, O. I. (2007). O paradoksah protsessa samoaktualizatsii lichnosti [On the paradoxes of the process of self-actualization of personality]. Priroda lichnosti: sushchnost', struktura i razvitie - The nature of personality: essence, structure and development. Moskva : Voskresenskaja tipografija [in Russian].

Naukove zabezpechennia rozvytku osvity $v$ Ukraini: aktualni problemy teorii i praktyky (do 25-richchia NAPN Ukrainy) [Scientific support of the development of education in Ukraine: actual problems of theory and practice (to the $25^{\text {th }}$ anniversary of NAPS of Ukraine)]. (2017). Kyiv : Vydavnychyi dim «Sam» [in Ukrainian].

Onufriieva, L. A. (2018). The theoretical and methodological analysis of Me-professional image as a component of future professionals' $\mathrm{Me}$ concept. S. D. Maksymenko, L. A. Onufrieva (Eds.). Problemy suchasnoi psykholohii - Problems of modern psychology: Collection of research papers of Kamianets-Podilskyi National Ivan Ohiienko University, G. S. Kostiuk Institute of Psychology of NAES of Ukraine, 39, 195-205. Kamianets-Podilskyi : Aksioma. DOI 10.32626/22276246.2018-39.195-205.

Penkova, O. I. (2018). Tsinnisni aspekty samorealizatsii osobystosti [Value aspects of self-realization of personality]. Aktualni problemy psykholohii - Actual problems of psychology: Collection of research papers of G. S. Kostiuk Institute of Psychology of NAES of Ukraine, VI, 14, 201-207. Kyiv - Zhytomyr : Vyd-vo ZhDU imeni I. Franka [in Ukrainian]. 
Savchyn, I. M. (2002). Samosvidomist shkoliara yak predmet profesiinoi uvahy vchytelia [A schooler's self-consciousness as a subject of teacher's professional attention]. Problemy zahalnoi ta pedahohichnoi psykholohii - Problems of general and pedagogical psychology : Collection of research papers of G.S. Kostiuk Institute of Psychology of NAES of Ukraine, IV, 5, 215-219. Kyiv [in Ukrainian].

Sardzhveladze, N. I. (1989). Lichnost' i eje vzaimodejstvie s sotsial'noj sredoj [Personality and his relationship with social sphere]. Tbilisi : Metsniereba [in Russian].

Sardzhveladze, N. I. (2007). Samootnoshenie lichnosti [Personality's selfattitude]. Psihologija samosoznanija - Psychology of self-consciousness. (pp. 174-207). Samara : Izdatel'skij dom «BAHRAH-M" [in Russian].

Serdiuk, L. Z. (2012). Psykholohiia motyvatsii uchinnia maibutnikh fakhivtsiv: systemno-synerhetychnyi pidkhid [Psychology of motivation of future students' training: a system-synergistic approach ]. Kyiv : Universytet «Ukraina» [in Ukrainian].

Stolin, V. V., \& Pantileev, S. R. (1988). Oprosnik samootnoshenija [Questionnaire on self-attitude]. Praktikum po psihodiagnostike: psihodiagnosticheskie materialy - Psychodiagnostic workshop: psychodiagnostic materials (pp. 123-130). Moskva : Izd-vo MGU [in Russian].

Yalanska, S. P., \& Atamanchuk, N. M. (2017). Psykholohiia formuvannia tolerantnoho seredovyshcha v umovakh novoi ukrainskoi shkoly [Psychology of Tolerant Environment Formation in Conditions of the Concept of «The New Ukrainian School»]. Nauka i osvita. Psykholohiia - Science and Education. Psychology, 1, 71-75. DOI http://doi. org/10.24195/2414-4665-2017-1-12 [in Ukrainian].

Chaika, G. (2016). Characteristics of self-concept of computer gamers. Social Welfare: Interdisciplinary Approach, 6 (1), 40-51. Retrieved from http://dx.doi.org/10.21277/sw.v1i6.235.

Chykhantsova, O. (2018). Features of Demonstration of Hardiness' Components of Personality. Science and Education, a New Dimension. Pedagogy and Psychology, VI (65), Issue 155, 58-60. Budapest. Retrieved from http://lib.iitta.gov.ua/710360/.

Grund, A., Fries, S., \& Rheinberg, F. (2018). Know Your Preferences: SelfRegulation as Need-Congruent Goal Selection. Review of General Psychology, 22, Issue 4, 437-451. Retrieved from https://doi.org/ $10.1037 /$ gpr0000159.

Huh, Y., \& Reigeluth, C. M. (2017). Self-Regulated Learning: The Continuous-Change Conceptual Framework and a Vision of New Paradigm, Technology System, and Pedagogical Support. Journal of Educational Technology Systems, 46, Issue 2, 191-214. Retrieved from https://doi.org/10.1177/0047239517710769. 
Maksymenko, S., \& Serdiuk, L. (2016). Psychological Potential of Personal Self-realization. Social Welfare: Interdisciplinary Approach, 6 (1), 92-100. Retrieved from http://dx.doi.org/10.21277/sw.v1i6.244.

Maslow, A. (1993). The Farther Reaches of Human Nature. New York : Penguin.

Rogers, C. A (1980). Way of Being. New York: Houghton Mifflin.

Ryan, R. M., \& Deci E. L. (2017). Self-Determination Theory: Basic psychological needs in motivation, development and wellness. New York, NY : Guilford Press Publishing.

Scholer, A. A., Miele, D. B., \& Murayama, K. (2018). New Directions in Self-Regulation: The Role of Metamotivational Beliefs. Current Directions in Psychological Science, 27, Issue 6, 437-442. Retrieved from https://doi.org/10.1177/0963721418790549.

Serdiuk, L. (2014). Personal Modus of Future Specialists' Self-Realization. Social Welfare: Interdisciplinary Approach, 4 (1), 71-80.

Shorgen, K. A., Jaehoon, L., \& Panko, P. (2016). An Examination of the Relationship between Postschool Outcomes and Autonomy, Psychological Empowerment, and Self-Realization. The Journal of Special Education, 51, Issue 2, 115-124. Retrieved from http://doi.org/ 10.1177/0022466916683171.

Waterman, A. S., Schwartz, S. J., \& Goldbacher, E. (2003). Predicting the Subjective Experience of Intrinsic Motivation: The Roles of Self-Determination, the Balance of Challenges and Skills, and SelfRealization Values. Personality and Social Psychology Bulletin, 29, Issue 11, 1447-1458. Retrieved from https://doi.org/10.1177/ 0146167203256907 .

\section{Яворська-Ветрова Ірина. Самоставлення і самоактуалізація сту- дентської молоді у контексті самодетермінації: аналіз емпіричного дослідження}

\section{АНОТАЦІЯ}

Статтю присвячено аналізу експериментального дослідження взаємозв'язків показників самоставлення та самоактуалізації у студентів. Самоставлення визначається як складна багаторівнева емоційно-ціннісна система, яка проходить в онтогенезі певні етапи розвитку на основі активного засвоєння інформації про власне "Я», інтегруючи й ієрархізуючи ії, забезпечує прогнозування своєї сочіальної ефективності та ставлення до себе оточуючих, регулює міжособистісні взаємини, постановку і досягнення цілей. Самоактуалізація розглядається центральним аспектом розвитку особистості та є виявом вродженої тенденції до зростання природного особистісного потенціалу. 
Аналіз даних дослідження особливостей самоставлення студентів дає підстави констатувати, що їх ставлення до себе має виражений позитивний емоційний модус. З’ясовано наявність взаємозв'язків показників самоставлення й самоактуалізації особистості. Зафіксовано, що висока позитивна оцінка себе пов'язана у досліджуваних зі здатністю цінувати свою гідність, поважати себе, безпосередньо і спонтанно виражати свої почуття, демонструвати емоції, намаганням бути відносно незалежним у своїх вчинках, прагненням керуватися в житті власними цілями, переконаннями, установками і принципами. Установлено, що, демонструючи здатність до швидкого встановлення суб'єкт-суб'єктних контактів, досліджувані виявляють здатність усвідомлювати і приймати власні прагнення й почуття, власні емоційні, у тому числі негативні, прояви, при цьому не відчуваючи потреби у зворотному зв'язку, не надто переймаючись емоційними реакціями оточуючих. Зауважено недостатню гармонійність процесу самоактуалізації у студентської молоді, розвитку здатності до конструктивної самореалізації. Обгрунтовано доцільність розробки і впровадження ефективних технологій сприяння розвитку особистісного потенціалу, усвідомлення себе для самореалізації та становлення психологічного благополуччя особистості.

Ключові слова: особистість, особистісний розвиток, самоставлення, самоактуалізація, самореалізація.

\section{Яворская-Ветрова Ирина. Самоотношение и самоактуализация студенческой молодежи в контексте самодетерминации: анализ эмпирического исследования}

\section{АННОТАЦИЯ}

Статья посвящена анализу экспериментального исследования взаимосвязей показателей самоотношения и самоактуализации у студентов. Самоотношение определяется как сложная многоуровневая эмоционально-ценностная система, которая проходит в онтогенезе определенные этапы развития на основе активного усвоения информации о собственном "Я», интегрируя и иерархизируя ее, обеспечивает прогнозирование своей социальной эффективности и отношения к себе окружающих, регулирует межличностные отношения, постановку и достижение целей. Самоактуализация рассматривается как центральный аспект развития личности и является проявлением врожденной тенденции к росту природного личностного потенциала. 
Анализ данных исследования особенностей самоотношения студентов дает основания констатировать, что их отношение к себе имеет выраженный позитивный эмоциональный модус. Показано наличие взаимосвязей показателей самоотношения и самоактуализации личности. Зафиксировано, что высокая положительная оценка себя связана у исследуемых со способностью ценить свое достоинство, уважать себя, непосредственно и спонтанно выражать свои чувства, демонстрировать эмоции, со стремлением быть относительно независимым в своих поступках, руководствоваться в жизни собственными целями, убеждениями, установками и принципами. Установлено, что, демонстрируя способность к быстрому установлению субъект-субъектных контактов, исследуемые проявляют способность осознавать и принимать собственные стремления и чувства, собственные, в том числе негативные, эмоциональные проявления, при этом не чувствуя потребности в обратной связи, не учитывая эмоциональные реакции окружающих. Указано на недостаточную гармоничность процесса самоактуализации у студенческой молодежи, развития способности к конструктивной самореализации. Обоснована целесообразность разработки и внедрения эффективных технологий способствования развитию личностного потенциала, осознания себя для самореализации и становления психологического благополучия личности.

Ключевые слова: личность, личностное развитие, самоотношение, самоактуализация, самореализация. 